\title{
Formation of Barium Titanate : Reactivity of Raw Materials
}

\author{
Hiroaki TAGAWA* and Junichi OHASHI*
}

\begin{abstract}
Formation of barium titanate with emphasis on chemical reactivity of raw materials was studied by thermogravimetry and X-ray diffraction methods. The materials used were nitrate, carbonate, hydroxide and oxalate of barium, and hydrate, anatase and rutile of titanium dioxide. Of these barium compounds, the oxalate was converted to the carbonate before the salt reacted with titanium dioxide. The chemical reactivity of the reagents was compared from the standpoints of the initital and final temperatures of the reactions in $\mathrm{TG}$ and conversion to the $\mathrm{BaTiO}_{3}$ phase. The product was $\mathrm{BaTiO}_{3}$ for the reaction of $\mathrm{Ba}\left(\mathrm{NO}_{3}\right)_{2}$ with $\mathrm{TiO}_{2}$, and $\mathrm{BaTiO}_{3}$ accompanied with other titanates for the other reactions. The decreasing order of the reactivity for $\mathrm{Ba}$ salts was : nitrate $>$ carbonate $\doteqdot$ hydroxide, and that for titanium dioxide was : anatase $>$ hydrate $\doteqdot$ rutile. Weight loss in $T G$ was in agreement with that due to the formation of the titanate.
\end{abstract}

\section{Introduction}

There are seven compounds in the system barium-titanium-oxygen : $\mathrm{Ba}_{2} \mathrm{TiO}_{4}, \quad \mathrm{BaTiO}_{3}$, $\mathrm{BaTi}_{2} \mathrm{O}_{5}, \mathrm{Ba}_{6} \mathrm{Ti}_{1}, \mathrm{O}_{40}, \mathrm{Ba}_{4} \mathrm{Ti}_{13} \mathrm{O}_{30}, \mathrm{BaTi}_{4} \mathrm{O}_{9}$ and $\mathrm{Ba}_{2} \mathrm{Ti}_{9} \mathrm{O}_{20}{ }^{1)}$. Of these compounds, $\mathrm{BaTiO}_{3}$, which has the tetragonal perovskite structure ${ }^{2)}$, is the most important compound of ferroelectric materials, and it has been mainly studied from the standpoint of physical properties. Barium titanate is also expected to be a candidate of a ceramicform agent immobilizing high-level radioactive waste, as perovskite-related structure $\left(\mathrm{BaTiO}_{3}\right)$ and hollandite-related structure $\left(\mathrm{BaAl}_{2} \mathrm{Ti}_{6} \mathrm{O}_{10}\right.$ or $\left.\mathrm{Ba}_{2} \mathrm{Ti}_{9} \mathrm{O}_{20}\right)$. Barium is a main constituent of fission products, and the content in fission products increases with time due to radioactive decay: That is, the content ratio is $3.98 \mathrm{wt} \%$ just after separated through reprocessing, and it increases to 5.17 and $7.97 \mathrm{wt} \%$ after 10 and 1000 years, respectively ${ }^{3)}$. Thus titanate has been studied as a matrix immobilizing highlevel radwaste, for example SYNROC, which has been named as the abbreviation of SYNthetic $\mathrm{ROCk}^{4}$.

Barium titanate is generally produced by the reaction of barium carbonate with titanium dioxide at high temperatures above $1000^{\circ} \mathrm{C}$, and kinetics and mechanism of the reaction have been studied $^{5 \sim 10}$. If a highly chemical, reactive agent is used as a starting material, firing temperature

* Institute of Environmental Science and Technology, Yokohama National University (156 Tokiwadai, Hodogaya$\mathrm{ku}$, Yakohama 240)

Key Words: Barium, Titanium, Barium Titanium, Solid State Reaction, Thermogravimetry will be lowered. In the present paper, the formation of barium titanate was examined by thermogravimetry (TG) and X-ray diffraction (XRD) with emphasis on chemical reactivity of starting materials.

\section{Experimental}

\subsection{Materials}

Nitrate, carbonate, hydroxide and oxalate of barium (GR grade) were provided by Kanto Chemical Co. Anatase and rutile of titanium dioxide (EPR grade) were provided by Wako Chemical Co. Titanium dioxide hydrate was prepared by hydrolysing titanium sulfate solution with ammonia ${ }^{11}$. The composition was $\mathrm{TiO}_{2} \cdot \mathrm{H}_{2} \mathrm{O}$.

All reactions were porformed with samples in a form of compacted cylinder. A barium salt and titanium dioxide were thoroughly mixed at an equimolar ratio in an agate mortar, and compacted at $3 \mathrm{t} \mathrm{cm}^{-2}$ into the cylindrical, $7 \mathrm{~mm}$ in diameter and about $5 \mathrm{~mm}$ in height. The weight of a pellet was about $300 \mathrm{mg}$.

\subsection{Apparatus and procedure}

Experiments for studying chemical reactivity were carried out by use of a thermobalance with a gas supply system and a vacuum pump. An electrobalance (Cahn Co., USA, Model 2000) was used as the thermobalance. The sample in a platinum crucible was heated at a heating rate of $5^{\circ} \mathrm{C} \mathrm{min}-1$, unless otherwise specified, in a stream of air or other gases (flow rate, $100 \mathrm{~cm}^{3} \mathrm{~min}^{-1}$ ). The emperature of the sample was measured with a $\mathrm{Pt} / \mathrm{Pt}+13 \% \mathrm{Rh}$ 
thermocouple placed close to the crucible inside the reaction tube. The details of the apparatus and the procedure are described elsewhere ${ }^{11}$.

Some samples were examined by use of a TG-DTA apparatus (Shiku Riko Co., Thermal analyser, type 5000 ) under the same condition in the thermobalance.

XRD for powder specimens was performed by a diffractometer (Rigaku Denki Co., type Rad-1 A) with $\mathrm{CuK} \alpha$ radiation monochromatized with a bent graphite crystal.

\section{Results and Discussion}

\subsection{Reaction of barium nitrate with titanium dioxide}

TG curves of decomposition for barium nitrate and titanium dioxide hydrate, and of the reaction of both the compounds in a flow of air are shown in Fig. 1. In all the figures for $T G$ curves including Fig. 1, theoretical weight loss is taken as $100 \%$.

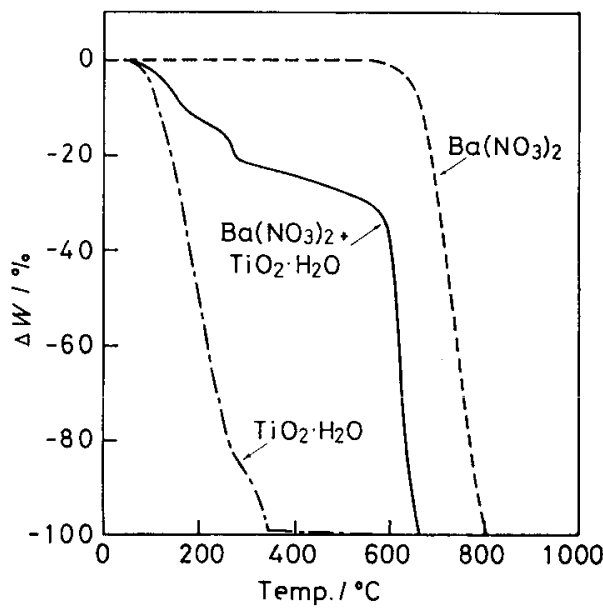

Fig. 1 TG curves of decompositions of barium nitrate and titanium dioxide hyd. rate, and of reaction of barium nitrate with titanium dioxide hydrate in a flow of air Heating rate $: 5^{\circ} \mathrm{C} \mathrm{min}^{-1}$

When heated in air, barium nitrate is changed into barium oxide by releasing nitrogen dioxide and oxygen. As seen in the figure, the thermal decomposition occurred at about $600^{\circ} \mathrm{C}$ and finished at $800^{\circ} \mathrm{C}$. The decomposition of the nitrate, of which the melting temperature is $575^{\circ} \mathrm{C}$, occurs in liquid phase. On heating the titanium dioxide hydrate in air, weight loss of the sample began just above room temperature,

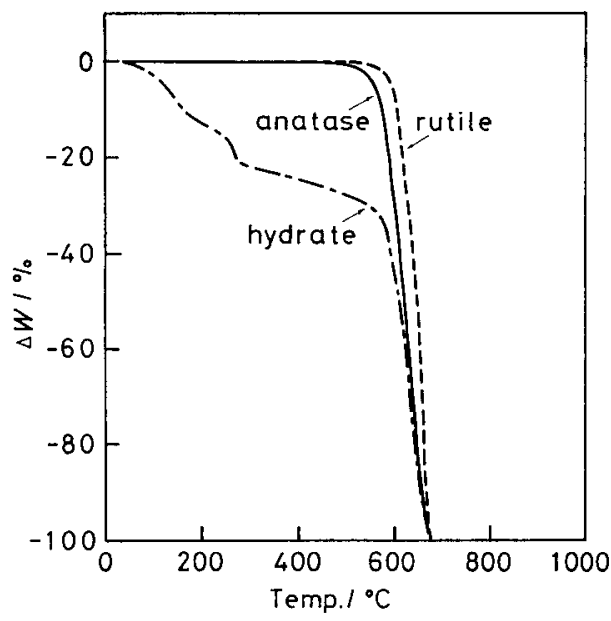

Fig. 2 TG curves of reactions of barium nitrate with hydrate, anatase and rutile of titanium dioxide in a flow of air Heating rate $: 5^{\circ} \mathrm{C} \mathrm{min}{ }^{-1}$

and finished at $600^{\circ} \mathrm{C}$. The reaction of barium nitrate with titanium dioxide hydrate occurred at $560^{\circ} \mathrm{C}$, at which barium nitrate is solid phase. The rate of the weight loss in the reaction was larger than that in the decomposition of barium nitrate.

TG curves of the reactions of barium nitrate with three forms of titanium dioxide are shown in Fig. 2. The initial temperatures of the reactions of the nitrate with the hydrate, anatase and rutile were 550,470 and $550^{\circ} \mathrm{C}$, respectively. These temperatures were lower than the initial temperature of the decomposition of barium nitrate. Kubo and Shinriki studied on the reaction of barium nitrate with anatase at a heating rate of $1.5^{\circ} \mathrm{C} \mathrm{min}^{-1}$ in air, and obtained $530^{\circ} \mathrm{C}$ as the initial temperature ${ }^{12}$. XRD was carried out for the samples taken out at the final temperatures, and it was confirmed that the weight loss corresponded to the formation of barium titanate. The products were the single phase of $\mathrm{BaTiO}_{3}$ in any form of titanium dioxide. Thus it is thought that the reaction of barium nitrate with titanium dioxide yields directly the titanate as $\mathrm{Ba}\left(\mathrm{NO}_{3}\right)_{2}+\mathrm{TiO}_{2}$ $=\mathrm{BaTiO}_{3}+2 \mathrm{NO}_{2}+1 / 2 \mathrm{O}_{2}$.

\subsection{Reaction of barium carbonate with titanium dioxide}

TG curves of the reactions of barium carbonate with three forms of titanium dioxide in air, together with the thermal decomposition 


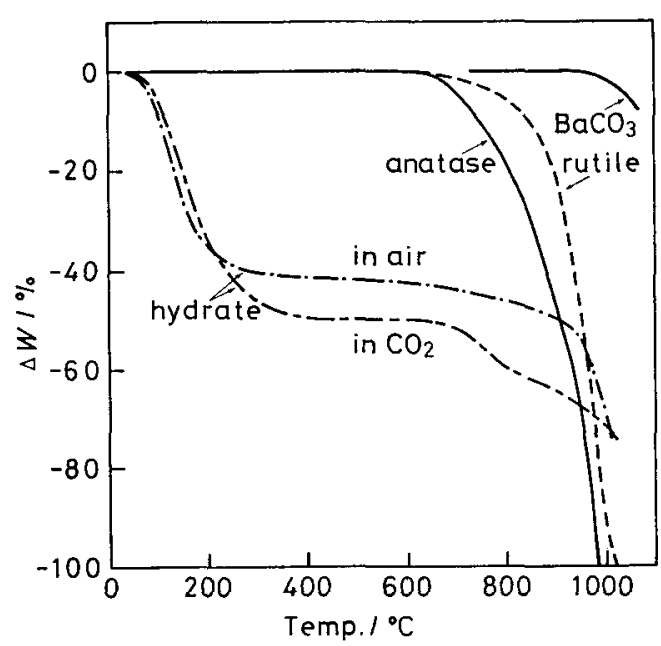

Fig. 3 TG curves of decomposition of barium carbonate, and of reactions of barium carbonate with hydrate, anatase and rutile of titanium dioxide in a flow of air

Heating rate $: 5^{\circ} \mathrm{C} \min ^{-1}$

curve of barium carbonate, are shown in Fig. 3. When barium carbonate was heated, the weight loss occurred at $915^{\circ} \mathrm{C}$, at which the equilibrium carbon dioxide pressure was calculated to be $1.6 \times 10^{-4} \mathrm{~atm}$. The decomposition temperature at $p_{\mathrm{CO}_{2}}=1 \mathrm{~atm}$ is $1490^{\circ} \mathrm{C}$. The initial temperatures of the reactions of barium carbonate with the hydrate, anatase and rutile were 655,620 and $650^{\circ} \mathrm{C}$, respectively. These temperatures were much lower than that of the decomposition of barium carbonate. In each reaction, the existence of the titanate near the initial temperature was detected by XRD. The conversion ratio calculated from the weight loss in TG curves was in agreement with that due to the formation of the titanate in any form of titanium dioxide. The product was mainly $\mathrm{BaTiO}_{3}$ accompanied with a little amount of $\mathrm{Ba}_{2} \mathrm{TiO}_{4}$. Templeton and Pask ${ }^{9}$, however, obtained the results that the main product in the reaction of barium carbonate with anatase at 900 and $1050^{\circ} \mathrm{C}$ was $\mathrm{Ba}_{2} \mathrm{TiO}_{4}$, not $\mathrm{BaTiO}_{3}$. They used the anatase heat-treated at $1000^{\circ} \mathrm{C}$ for $6 \mathrm{~h}$ in air. According to our results by scanning electron microscope, particles of anatase were sintered and grown up under such a condition, in addition to the transformation to rutile, thus the reactivity of titanium dioxide in a solid-state reaction was lowered. When the rate-determining step is a diffusion process of barium atoms through the product layer, it may be thought that $\mathrm{Ba}_{2} \mathrm{TiO}_{4}$ is predominantly formed in a product layer, which is constructed from the compounds as $\mathrm{BaCO}_{3} / \mathrm{B}_{2} \mathrm{~T} / \mathrm{BT} / \mathrm{BT}_{2} /$ $\mathrm{B}_{6} \mathrm{~T}_{17} / \mathrm{B}_{4} \mathrm{~T}_{13} / \mathrm{BT}_{4} / \mathrm{B}_{2} \mathrm{~T}_{9} / \mathrm{TiO}_{2}$, where $\mathrm{B}$ is $\mathrm{BaO}$ and $\mathrm{T}$ is $\mathrm{TiO}_{2}$.

For the reactions of barium carbonate with the hydrate and anatase of titanium dioxide in carbon dioxide, where TG curve of the reaction of barium carbonate with anatase is shown in Fig. 7, the initial temperatures were 720 and $680^{\circ} \mathrm{C}$, respectively. These temperatures are much lower than that of the decomposition of barium carbonate. As barium carbonate is not decomposed even partially, the carbonate is thought to react directly with titanium dioxide: $\mathrm{BaCO}_{3}+\mathrm{TiO}_{2}=\mathrm{BaTiO}_{3}+\mathrm{CO}_{2}$.

\subsection{Reaction of barium hydroxide with titanium dioxide}

Figure 4 shows TG curves of the dehydration of barium hydroxide octahydrate $\mathrm{Ba}(\mathrm{OH})_{2}$. $8 \mathrm{H}_{2} \mathrm{O}$ and the reactions of three forms of titanium dioxide. Melting temperatures of $\mathrm{Ba}(\mathrm{OH})_{2} \cdot 8 \mathrm{H}_{2} \mathrm{O}$ and the anhydrate are 77 and $408^{\circ} \mathrm{C}$, respectively. According to DTA at a heating rate of $5^{\circ} \mathrm{C} \mathrm{min}{ }^{-1}$, the octahydrate was once molten at $78^{\circ} \mathrm{C}$, where the hydroxide was dissolved in the crystal water, then the

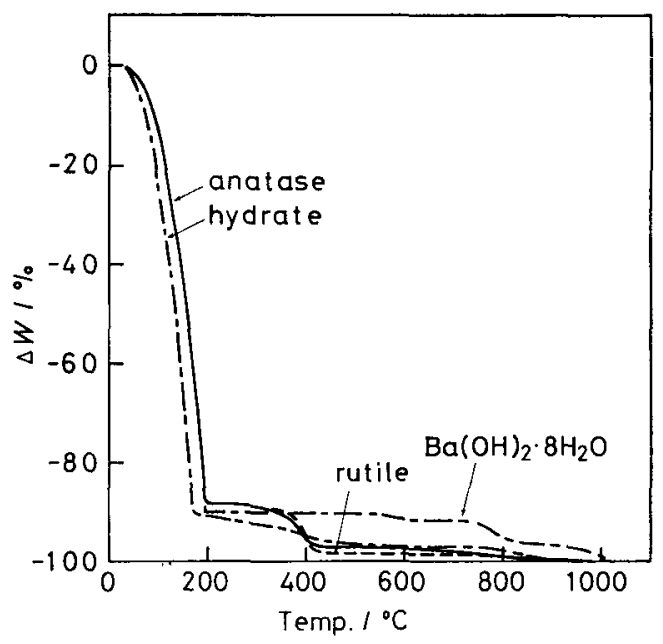

Fig. 4 TG curves of reactions of barium hydroxide octahydrate with hydrate, anatase and rutile of titanium dioxide in a flow of air

Heating rate $: 5^{\circ} \mathrm{C} \mathrm{min}^{-1}$ 
hydroxide became the anhydrate at about $160^{\circ} \mathrm{C}$ as the water was gradually evaporated, next the hydroxide was molten at $400^{\circ} \mathrm{C}$. The decomposition temperature of the hydroxide is $1000^{\circ} \mathrm{C}$. The TG curve of the hydroxide in Fig. 4 showed to become the anhydrate up to $200^{\circ} \mathrm{C}$, and to decompose above $400^{\circ} \mathrm{C}$. The carbonate should coexist in the hydroxide, but the carbonate was not distinguished from the hydroxide on TG curve.

When the mixture of barium hydroxide and the hydrate, anatase or rutile was heated in air at a heating rate of $5^{\circ} \mathrm{C} \mathrm{min}^{-1}$, weight loss occurred after the crystalline water was losed by $200^{\circ} \mathrm{C}$. The initial temperatures of these reactions were about $300^{\circ} \mathrm{C}$ or little less, but were not clearly defined. At about $400^{\circ} \mathrm{C}$, the melting temperature of $\mathrm{Ba}(\mathrm{OH})_{2}$, two third of the theoretical weight loss occurred. If the weight loss corresponds to the formation of barium titanate, the Ba-to-Ti atom ratio of the product becomes about two third, $i .$. . the product might be an equimolar mixture of $\mathrm{BaTi}_{2} \mathrm{O}_{5}$ and $\mathrm{BaTiO}_{3}$. Weight loss continued above $400^{\circ} \mathrm{C}$, and finished at $980^{\circ} \mathrm{C}$. The product was not the single phase of $\mathrm{BaTiO}_{3}$.

\subsection{Reaction of barium oxalate with titanium dioxide}

As previously reported ${ }^{11}$, the reactions of strontium salts of carboxylic acids with titanium dioxide, where formate, acetate and oxalate were used as carboxylic acids, were deduced to the reaction of strontium carbonate with titanium dioxide. That is, strontium salts of carboxylic acids were converted into the carbonate before the salts reacted with titanium dioxide. Thus, in order to confirm whether the reaction behaviors for strontium are applied to that for barium, the oxalate containing only carboxylic group was examiend as a starting material.

Figure 5 shows TG curves of the reaction of barium oxalate with three forms of titanium dioxide in air. In each reaction, weight loss occurred in three steps: The first step was dehydration of barium oxalate hydrate by $200^{\circ} \mathrm{C}$, and the second was decomposition of the oxalate at about $400^{\circ} \mathrm{C}$. From the figure, it is seen that the oxalate is decomposed without yielding the titanate, and changed into the carbonate as follows: $\mathrm{Ba}(\mathrm{COO})_{2}+1 / 2 \mathrm{O}_{2}=\mathrm{BaCO}_{3}$

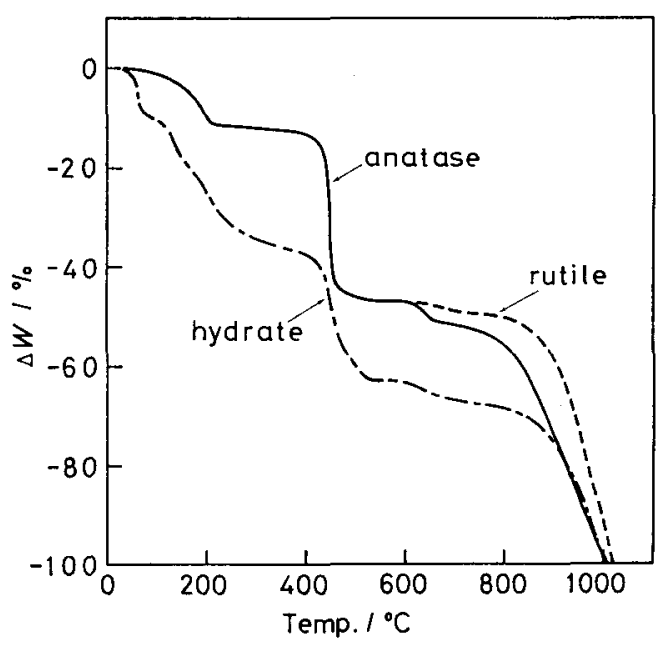

Fig. 5 TG curves of reactions of barium oxalate monohydrate with hydrate, anatase and rutile of titanium dioxide in a flow of air

$$
\text { Heating rate }: 5^{\circ} \mathrm{C} \mathrm{min}^{-1}
$$

$+\mathrm{CO}_{2}$. The third step was the reaction of the newly formed carbonate with titanium dioxide. This reaction occurred above $600^{\circ} \mathrm{C}$ for the hydrate, and $610^{\circ} \mathrm{C}$ for anatase and rutile. As these temperatures are lower than those of the preceedingly described reactions of barium carbonate with three forms of titanium dioxide, the carbonate formed in situ is known to have higher chemical reactivity than barium carbonate as a reagent.

\subsection{X-ray diffraction patterns of products}

In order to examine whether the weight loss corresponds to the formation of barium titanate, XRD was carried out for the samples taken out at the final temperature in TG. The dif. fraction patterns of the products obtained by three reactions of nitrate, carbonate and hydroxide with anatase are shown in Fig. 6. The final temperature was varied by the species of barium salts : The temperatures for the reactions with nitarte, carbonate and hydroxide of barium were 660,980 and $990^{\circ} \mathrm{C}$, respectively. Heating times to the final temperatures, therefore, were 130,190 and $190 \mathrm{~min}$, respectively. As seen in the figure, the reaction of the nitrate with anatase yielded only $\mathrm{BaTiO}_{3}$, and the reactions of carbonate and hydroxide with anatase yielded other titanates besides $\mathrm{BaTiO}_{3}$. All the diffraction patterns showed no raw materials in the 

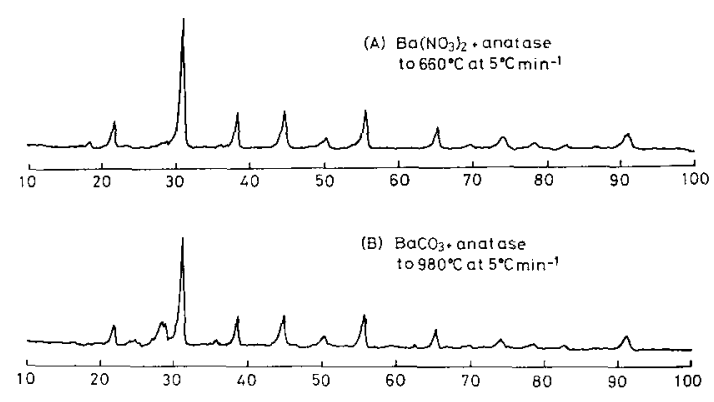

(C) $\mathrm{Ba}(\mathrm{OH})_{2} \cdot 8 \mathrm{H}_{2} \mathrm{O}$. anatase $0990^{\circ} \mathrm{Cot} 5^{\circ} \mathrm{Cmin}^{-1}$

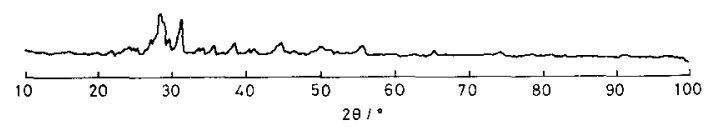

Fig. 6 X-ray diffraction patterns of products prepared by reactions of barium salts with anatase in a flow of air at a heating rate of $5^{\circ} \mathrm{C} \min ^{-1}$

(A) Reaction of barium nitrate with anatase was carried out by heating to $660^{\circ} \mathrm{C}$; (B) Reaction of barium carbonate with anatase by heating to $980^{\circ} \mathrm{C}$; and (C) Reaction of barium hydroxide octahydrate with anatase by heating to $990^{\circ} \mathrm{C}$

products.

\section{Concluding Remarks}

Chemical reactivity of raw materials in the formation of barium titanate was examined using initial temperature of the reaction in $T G$ and XRD. In the reactions of barium salts with titanium dioxide, the initial temperature of the titanate formation was raised in the following order, that is, the reactivity decreased : hydroxide $>$ nitrate $>$ carbonate. But the final temperature was raised in the order : nitrate $<$ hydroxide $<$ carbonate. The results of three bariumbearing salts using anatase are summarised in Fig. 7. From the standpoint of final temperature and formation of the single phase, it may be concluded that barium nitrate prefers to the other barium compounds as a raw material in the formation of $\mathrm{BaTiO}_{3}$.

The decreasing order of reactivity in three forms of titanium dioxide was as follows : anatase $>$ hydroxide $\doteqdot$ rutile. The hydrate was expected to have high chemical reactivity, but the dehydration below $300^{\circ} \mathrm{C}$ was not seen to contribute to the titanate formation. This dehydration might occur without lattice distortion, which contributes to enhance the reactivity,

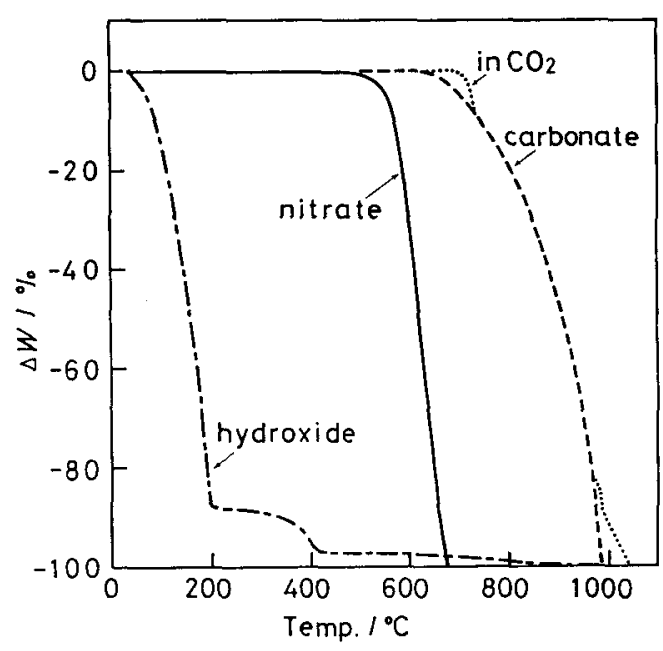

Fig. 7 TG curves of reactions of barium salts (nitrate, carbonate and hydroxide) with anatase in a flow of air The reaction of barium carbonate with anatase in $\mathrm{CO}_{2}$ is also shown. Heating rete $: 5^{\circ} \mathrm{C} \mathrm{min}-1$

and would have a tendency toward rather coagulation of particles of titanium dioxide. The order obtained here is the same to that obtained in the case of strontium titanate ${ }^{11)}$. There are some reports on the difference in chemical reactivity between anatase and rutile $e^{6,10,13)}$, and they are in agreement with ours. Heat of transition for anatase to rutile is not so large, less than $4 \mathrm{~kJ} \mathrm{~mol}^{-114}$, but the transition might be also operated as a driving force in the reaction using anatase.

\section{Reference :}

1) "Phase Diagrams for Ceramists", Amer. Ceram. Soc., Columbus, Ohio (1964), p. 98; "1975 Supplement (Vol.III)" (1975); and Vol. IV (1981), p. 92.

2) H.D. Megaw, "Crystal Structures: A Working Approach", W.B. Saunders Co., Philadelphia, p. 290 (1973).

3) K.J. Schneider and A.M. Platt, US-ERDA Report, BNWL-1900 (1974).

4) A.E. Ringwood, S.E. Kesson, N.G. Ware, W.O. Hibberson and A. Major, Geochem. J. 13, 14 (1979).

5) K. Kubo and K. Shinriki, Kogyo Kagaku Zasshi (J. Chem. Soc. Japan Ind. Chem. Sect.), 55, 49, 137 (1952); 57, 621 (1954).

6) L.K. Templeton and J.A. Pask, J. Amer. Ceram. Soc. 42, 212 (1959).

7) Y. Arai, T. Yasue, H. Takiguchi and T. Kubo, Nippon Kagaku Zasshi (J. Chem. Soc. Japan), 1611 (1974).

8) T. Yamaguchi, S.H. Cho, H. Nagai and H. Kuno, "Reactivity of Solids", Plenum, New York, p. 701 (1977). 
9) Y. Suyama and A. Kato, Bull. Chem. Soc. Japan 50, 1361 (1977).

10) T. Ishii, R. Furuichi, T. Nagasawa and K. Yokoyama, J. Thermal. Anal. 19, 467 (1980).

11) H. Tagawa, K. Kimura, T. Fujino and K. Ouchi, Denki Kagaku 52, 154 (1984).

12) K. Kudo K. Shinriki, Kogyo Kagaku Zasshi ( $J$.
Chem. Soc. Japan Ind. Chem. Sect.), 56, 335(1953).

13) T. Ishii, R. Furuichi and Y. Ohshima, J. Thermal Anal. 18, 527 (1980).

14) T. Mitsuhashi and O.J. Kleppa, J. Amer. Ceram. Soc. 62, 356 (1979).

(Received Jan. 9, 1984 ; Accepted Mar. 29, 1984)

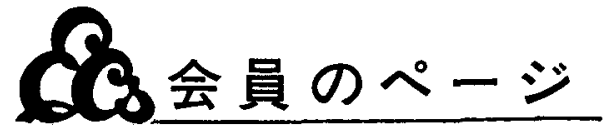

\section{有機およびバイオマス電気化学シンポジウム （米国電気化学会）に出席して}

さる5月6日より11 日まで米国オ八イオ州シンシナ ティー市で開かれた有機掞よびバイオマス電気化学に関 するシンポジウムに今回たをたま出席する機会に恵まれ ました。

これらのシンポジウムは第 165 回米国電気化学協会春 季年会（全講演数 445 件）の一環として行われたもので すが，出席者および講演発表者のいずれについても米国 以外からの者がかなり多く，国際学会の様相を強く呈し ておりました，発表講演数では，有機部門では 29 件， バイオマス部門では 14 件の計 43 件（内 2 件は都合に より中止）で，国別について言えば，米国勢が半数強で 最も多く，古とは多い順に英国，西独，日本，デンマー クカナダと続きました。

講演は 1 件あたり質疑応答を含めて 30 分間とい5予 定でしたが，予定時間を超過するケースもしばしばみう けられるほと，活発な討論がほとんどすべての講演につ いて行われ，この分野の国際的関心の高さをらかがうこ とができました．参加者も約 $30 \sim 40$ 人程度で，じっく りとつっこんだ討論をするのに適当な人数であったと思 われます、筆者の偏見と独断を拉許し願って講演の内容 について若干の私見を述べますと，日頃学会や雑誌等で 見聞する日本の先生方の捛仕事を含めて考慮すれば，有 機電気化学，特に合成を志向する分野では，日本の水準 は大変高く，どちらかと言えば世界の先導的立場にある との感を深く致しました，その意味で，この分野での国 際学会を近い将来日本で開くことは, 世界的にも大いに
待望されているのではないかと，存じます，外国勢の講 演のらち二, 三興味深いものを拾いあげますと，1）E. K. Miller 教授 (米国ミネソタ大学) らによるジメチル ピリドリウム・カチオンが通常では還元され難い有機化 合物（たとえばベンゾフランや共役ジェン）の電極還元 に怙ける良好なメディエー夕（電子触媒）になり得る上 の事実 2) H. Lund 教授 (デンマーク Aarhus 大学) らによる,アリルアルコール類のヨウ化ナトリウムを含 む酸性水溶液中での電極還元（水銀陰極）により，二重 結合の転位を伴う水酸基の脱離反忍の結果末端オレフィ ンが生成するといら結果，3）W. Farnung 博士（へキ スト社, 西独) による,トリアルキルホスファイト存在 下に抬ける芳香族化合物の陽極酸化によるアリールホス フォネートの合成，などがあったと存じます。また， D.E. Danly 博士（米国モンサント社）が“アジポニト リルの電気化学的製造法の開発と企業化”についての功 績により，Nora-Diamond-Shamrock 賞を受賞され， Banquet の席上にてその記念講演が行われ，多くの人 々から惜しみない賛辞が送られました。

日本からのこのシンポジウムへの参加者は，野中 勉 (東工大総合理工)，鳥居 滋 (岡山大工) 执よび筆者の 3 名でありました．米国内拉よび欧州の国々からこられ ていたここの分野でよく活躍されている方々のかなりの 人達は，何度か日本にも来られた経験があり，私ども日 本人 3 人とも以前より面識なり，親交のある人が多かっ たので, 講演の合間やミキサーなどでも親しく卒直な意 見の交換を行ったり，旧交をあたためあったり，再会を 約束しあったりすることが出来，幸いであったと思って おります。

(大阪市立工業研究所 西口郁三) 